\title{
THE IMPACT OF ECOTOURISM ON LIVELIHOOD AND NATURAL RESOURCE MANAGEMENT IN ESELENKEI, AMBOSELI ECOSYSTEM, KENYA
}

\author{
Z. A. OGUTU* \\ Kenyatta University, Nairobi, Kenya \\ Received 25 September 2001; Accepted 19 January 2002
}

\begin{abstract}
This paper presents the impact of ecotourism ${ }^{1}$ on livelihood and natural resource management in the periphery of Amboseli Biosphere Reserve in Kenya. Ecotourism initiatives that have been introduced by Porini Ecotourism, a private investor, are benefiting Eselenkei Group Ranch in terms of income, improved infrastructure, employment opportunities and exposure. Over US\$5000 is received annually as land rent, gate fee and bed charges. Twenty-six Maasai men are employed for the upkeep of project facilities. The community's capacity to facilitate resource-related conflicts has improved following support from development institutions. An expanding livelihood base is reducing local vulnerability to disaster and people-wildlife conflicts. The numbers of resident wildlife species in the conservation area have increased due to regeneration of woody species and reduced frequency of livestock.

Despite the achievements, ecotourism is threatened by cultivation. The latter is jeopardizing conservation efforts, as the area frequented by wildlife is being lost and people-wildlife conflicts intensified. Another dilemma is that the Eselenkei community is not effectively participating in ecotourism a situation that is associated with inadequate management and negotiation skills in the group ranch committee. The latter requires leadership and microenterprise management skills if earnings from ecotourism are to be effectively invested in alternative sources of livelihood, to reduce current and potential conflicts. There is also need to build the community's capacity for the promotion of activities that compliment ecotourism. Frequent breakdown of community boreholes lead to dependence on the conservation area for water during prolonged drought, intensifying conflicts between livestock and wildlife. Copyright (C) 2002 John Wiley \& Sons, Ltd.
\end{abstract}

KEY WORDS: Amboseli ecosystem; Kenya; Maasai; livelihood; ecotourism; natural resource management

\section{THE STUDY AREA AND BACKGROUND}

Eselenkei group ranch is in the periphery of Amboseli Biosphere Reserve in Kajiado District of Kenya. It has an area of 74794 ha and a population of about 10000 IlKisonko Maasai. A large portion of the ranch is arid with highly variable rainfall amounts ranging between 300 and $500 \mathrm{~mm} \mathrm{yr}^{-1}$. Low and unpredictable rainfall and lack of good aquifers make water resources a constraint to development (Potter, 1989). Vegetation resources are scanty, being retarded by overgrazing and the harsh physical conditions. The soil types include sandy loam and black cotton soils that are susceptible to erosion.

Although Eselenkei Group Ranch supports a large number of Maasai livestock, it is a dispersal area for wildlife of the Amboseli Biosphere Reserve (Ecosystems, 1982). Lying north of the Amboseli ecosystem, this ranch is advantaged by the ecotone conditions, which attract different livelihood activities such as charcoal burning, cultivation and livestock keeping. The latter competes favourably with wildlife conservation.

Eselenkei Group Ranch has lagged behind in terms of national development. The social and infrastructural amenities are limited, being provided mainly by the Catholic Diocese of Kajiado at Lenkesim. There has been no

\footnotetext{
*Correspondence to: Dr Z. A. Ogutu, Ecotourism, Kenyatta University, PO Box 43844, Nairobi, Kenya. E-mail: zaogutu@avu.org

${ }^{1}$ Referring to low-impact nature-based tourism packages that benefit local communities and the national government while helping to conserve the resource base (Kenya Wildlife Service (KWS), unpublished report, 2001).
} 
government effort to support livelihood activities since 1996. Maasai traditional pastoralism remains the only adapted form of livelihood (Southgate and Hume, 1996; Barrow et al., 1993). A mixture of livestock is raised, with the East African zebu being popular. Loss of livestock due to drought and diseases has necessitated alternative livelihoods such as cultivation and income-generating activities. The Department of Agriculture does not support cultivation because the Group Ranch has low potential for crop production (Divisional Officer, Loitokitok, pers. comm.). Cultivation is therefore an individual effort following exposure to neighbouring communities in Loitokitok Division and Machakos District. During the wet season, scattered croplands are a common feature around homesteads. Irrigation farms have emerged along the Kilimanjaro-Mashuru water pipeline under the National Water Conservation and Pipeline Corporation that is meant to serve townships in Kajiado and Machakos Districts. In response to seriously needed water resources, some members have dug shallow wells along river valleys to obtain water for horticultural farming. Cultivation is a domain of the young Maasai men (aged between 25 and 45 years) who grow different food crops for subsistence and sale.

Crop-wildlife interaction is generating new dimensions of conflicts. Stray wildlife trample on crops leading to them being killed by angry farmers. Respondents justify this based on the costs incurred due to crop damage. Horticultural farming along the water pipeline is, for instance, costly. Farmers use agricultural inputs, hired labour and piped water, that involves monthly payment of the water bill. Respondents estimated an expenditure of up to about 2800 Kenyan Shillings (US\$35) on labour hire, KES2000 (US\$25) on agrochemicals and KES2160 (US\$27) on the water bill per acre of tomatoes per season. The total amount (of US\$87) involved has an implication on income at household level, which explains the seriousness of crop damage on local livelihood. In the past, KWS compensated farmers for loss/damage of crops. Due to irregularities associated with the transaction of the claims, the compensation scheme was scrapped by an Act of the Parliament in 1991. The affected communities insist that this ban be lifted if they have to continue living with wildlife (DfID-NRSP, unpublished report, 2000; KWS, unpublished report, 2001).

In May 1997, the Group Ranch Committee entered into a lease agreement for 16 ha of the Eselenkei Conservation Area (ECA) with a private developer for the Porini Ecotourism Project (PEP). The objective of PEP is to promote low tourism and wildlife conservation, and generate income and economic benefits for the community to avoid dependence on pastoralism alone and, reduce wildlife-related conflicts. PEP has an exclusive right to the leased portion, initially for 15 years. Given that ECA serves as a dry season grazing land for Maasai traditional pastoralism, some members remain opposed to the leased portion. This is mainly because the benefits accruing from the project are not equitably distributed.

\section{RESEARCH METHODOLOGY}

This paper is based on data collected between January and March 1999 using semistructured interviews, and updated using information gathered during subsequent local meetings. A process of triangulation was ensured, whereby key informants and focused groups were interviewed and different sites (e.g. cultivated plots, ECA and water points) visited. Snowball sampling procedure was used. This is a procedure where the researcher starts off with one informant who in turn introduces the next person she or he considers useful to the investigation. Interview questions touched on livelihood options, wildlife conservation and natural resource management. The operation of the group ranch committee was also investigated.

A total of 35 individuals (19 pastoralists, 8 agropastoralists, 2 community wildlife scouts, 3 wildlife officers and 3 government administrators) and 3 women's groups were interviewed during the two visits. Pertinent livelihood issues arising from the interviews were discussed during consultative meetings held between May 2000 and June 2001. This study has also used different reports to compliment field data and put the findings in context.

\section{IMPACT OF ECOTOURISM}

The Porini Ecotourism Project (PEP) is a joint venture between the Eselenkei community and Porini Ecotourism, a UK-Nairobi-based private developer. Since its inception in 1997, PEP has contributed to local livelihood and natural resource management, differently. 


\section{Impacts on Livelihood}

The community is benefiting from a fee that is paid by Porini Ecotourism for the lease of the land. About 16 ha of ECA have been leased at a fee of US\$5300 per year with a 10 per cent increment. Over and above, the community receives amounts ranging between US\$500 and 1200 per year as gate fees and bed charges paid by tourists who visit the conservation area. The Group Ranch Committee uses these earnings to support different community livelihood initiatives such as the construction of schools, payment of hospital bills and maintenance of boreholes.

Porini pays monthly salaries to 26 members of staff, drawn from the Eselenkei community, who serve at the camps. The workers include security guards, hotel attendants, road maintenance and clerical staff. More and more local people are complementing their sources of income with payments received as casual workers. Up to 20 casual workers are absorbed by Porini especially during construction and repairs (Intermediate Technology Development Group-Eastern Africa (ITDG-EA), unpublished report, 2001). Individual households benefit from the sale of firewood and charcoal and the different foodstuffs that are sold at the camps. Earnings received from ecotourism are used in various ways, including purchase of livestock drugs and steers, initiatives that are contributing towards livelihood in general and local food security in specific. There are limitations with these gains, which include dominance by a few households and unwillingness by the private developer to rely on locally available alternative materials and goods. The latter situation can partly be explained by inadequate skills in the community for marketing of local goods. Most people (including members of the group ranch committee) lack exposure to the outside world. There is also lack of awareness among the local people on how tourist demand dictates the type of goods and materials purchased at the camp. Despite these constraints, nyama choma (roasted meat) is now on the menu in the camps creating a market for local goats.

The Eselenkei community is benefiting from improved infrastructural systems. These include over $70 \mathrm{~km}$ earth road network that has been constructed by Porini in the conservation area and outside. The all-weather road has improved community access to outside markets. To increase the number of resident wildlife, PEP has constructed three water pans and two boreholes within the conservation area. These water sources have reduced competition for grazing resources between livestock and wildlife. After consultations with the management, Eselenkei community is allowed to use grazing resources in the project site, especially during prolonged drought or following a breakdown of community boreholes. Access to the new water sources has reduced community vulnerability to drought-related disasters. The majority of households, for instance, did not move their livestock to distant grazing areas during the 1999-2000 drought. Community contact with the outside world has improved following access to a telephone line provided by Porini to serve the Community Conservation Liaison Officer.

More benefits to the Eselenkei community come in a form of contribution from the Kenya Wildlife Service (KWS), the custodian of wildlife resources in Kenya. KWS has been instrumental in the establishment of PEP. The organization facilitated negotiations between the community and Porini Ecotourism and has, through workshops and exposure tours, helped to build trust for the project among the Eselenkei members. In recognition of the community's willingness to share grazing resources with roaming wildlife, KWS contributes KES 1 million (US\$12 500), annually. Similar amounts are paid to all communities that have agreed to share grazing resources with wildlife (Barrow et al., 1993; KWS, unpublished report, 2001). This contribution is meant to offset the costs incurred by the communities for living with wildlife and, build trust and ownership of wildlife resources among the local people. The positive impact of this contribution, notwithstanding, the beneficiaries have expressed disappointment over this amount, pointing out that it is too little compared with the costs incurred (KWS, unpublished report, 2001). This is partly associated with poor negotiation skills by the Group Ranch Committee coupled with limited knowledge of market value of resources involved and the implications of the lease agreement on the local economy.

Just like the earnings from PEP, the annual contribution by KWS is used to support community projects. The major investment of ecotourism-related earnings is payment of school fees for needy students in Secondary Schools and, at national universities and colleges. The respondents criticized use of most of the earnings in paying school fees and the failure by the Group Ranch Committee to address other needs, especially those of majority of the members without children at school or whose children drop out at primary level. The affected individuals called 
for diversification of the investment of wildlife-related earnings beyond community projects. The women's groups have, for instance, approached the group ranch committee for funding to boost their small-scale business. Due to Maasai cultural settings that hardly recognize women's needs (Southgate and Hume, 1996), this request has not been favourably considered.

Awareness and mobilization workshops that were funded by KWS, the African Wildlife Foundation (AWF), African Centre for Conservation (ACC) and Porini Ecotourism Ltd. have improved the capacity of individuals. The members have been empowered through exposure tours organized to Narok and Laikipia Districts and other parts of Kajiado District. In recognition of the community's willingness to participate in ecotourism, ITDG-EA facilitated an exposure tour in April 2001 (ITDG-EA, unpublished report, 2001). Selected members were exposed to different ecotourism complementary technologies in the Amboseli-Tsavo ecosystem and the Kenya coast. Tour participants identified fodder production, salt lick blocks and beekeeping as ecotourism complementary packages suitable to the local setting and conditions. A proposal has been developed and resources are being mobilized to implement selected packages.

Following exposure tours and consultative meetings (ITDG-EA, unpublished report, 2000; ITDG-EA, unpublished report, 2001a), Eselenkei members have identified various forums for sharing information on technological innovations and possible funding. Tour participants have been instrumental in facilitating negotiations on wildlife-related conflicts, using experience gained as they listened to narration by host institutions during the tours. Between February and July 2001, the Group Ranch Committee spearheaded three conflict negotiation meetings between Eselenkei and neighbouring communities. The discussions centred on poaching of resources from the conservation area (ITDG-EA, unpublished report, 2001b). Because of limited grazing resources in neighbouring group ranches, following subdivision of their group ranches and subsequent disappearance of resident lions for hunting, Maasai morans (warriors) from these communities invade the Eselenkei Conservation Area threatening the objectives of the PEP. Instead of the victims being accused in the law courts, this time the affected communities opted for negotiations. The culprits were each fined KES1500 (US\$19). The use of community-based conflict management strategies is becoming popular in Kenya because of its unique role in restoring mutual relationship between conflicting parties. Different NGOs including ITDG-EA, Oxfam and Action AID are building local capacity in conflict management (ITDG-EA 2001c).

Despite the different gains, reports from consultative meetings (ITDG-EA, unpublished report, 2000; ITDG-EA, unpublished report, 2001b) and existing literature (Barrow et al., 2000; Western, 1997) point to negative effects of ecotourism on livelihood. It is clear, for instance, that only a few members and/or institutions benefit. While the 'empowered few' help to mobilize locally available resources and create awareness among the rest of the members to participate in ecotourism initiatives (ITDG-EA, unpublished report, 2001a), the same members marginalize the rest of the community in benefiting from ecotourismrelated gains. Respondents confirmed that participants of training and exposure tours were mainly members of the Group Ranch Committee and/or their relatives. This anomaly is a potential source of conflicts and remains a threat to the viability of PEP. There is also contention from some members over the lease agreement. One ugly incident occurred in 1998 when a section of the membership brought the project to a halt complaining about the small amount of rental fee and its failure to address the needs of majority of members. This misunderstanding was settled following a meeting convened by the Divisional Officer, Loitokitok (DfIDNRSP, unpublished report, 2000). In 1999, a conservation committee was elected to ensure that funds generated from ecotourism are effectively channelled for the welfare of all members. Due to logistical problems, this committee was dissolved during a meeting held in April 2001. It is the Group Ranch Committee that is legally mandated to transact finances for the community (Divisional Officer, Loitokitok, pers. Comm.).

\section{Impacts on Natural Resource Management}

Ecotourism initiatives have made little positive impact on natural resource management. This is primarily because of lack of a national policy to integrate the initiatives with resource management and conservation. Conservation is still being influenced by the premise that wildlife needs to be protected to avoid overutilization and/or through competition with livestock (KWS, unpublished report, 2001). Despite this orthodox practice, there is evidence that 
the numbers of wildlife (including charismatic species) in ECA have either remained stable or increased. The number of resident lions stands at 14, having risen from almost none at the time of project inception in 1997. Resident giraffes, bird species and bush-loving wildlife have more than doubled following the increase in biomass and antipoaching campaigns spearheaded by community scouts. PEP has plans to introduce certain wildlife species to meet 'customer demand'. Following exposure tours, the community has expressed interest to introduce a rhino sanctuary.

Through exposure tours and consultative meetings, the community has been sensitized to the need to reduce livestock numbers. Local groups that are active in steer fattening are campaigning for fewer but healthy livestock. The membership consists of individuals who are promoting cultivation along Kilimanjaro-Mashuru water pipeline. To reduce pressure on natural pastures and dependence on ECA most of these members use complementary pastures such as nappier grass and maize stalks. Improved maintenance of community boreholes, dependence on piped water and the construction of private water pans has reduced competition between livestock and wildlife over water resources. Consequently, formerly degraded sites around community watering points are regenerating. Pressure on grazing resources has also reduced following the construction of two boreholes and three water pans in the conservation area. The different interventions have reduced competition on resources available for livestock, especially from resident wildlife species.

Abject poverty, improved contact with the outside world and increased numbers of resident wildlife have contributed to poaching. Although it is a taboo among the Maasai to kill game, youths are poaching wildlife for sale as game meat in Nairobi slums. Lack of appropriate consumptive utilization policy guidelines (Barrow et al., 2000; KWS, unpublished report, 2001) makes it difficult for local communities to effectively participate in cropping of wildlife. This situation leads to either the community losing valuable sources of income or the numbers of the specific animal species exceeding the ecological limit leading to environmental degradation. Respondents confirmed that poaching was caused by individuals who feel that they do not own ecotourism initiatives and that the KWS underpays them for the loss they incur (see also KWS, unpublished report, 2001, ITDG-EA, unpublished report, 2000). In a way, this reaction reflects a problem that ecotourism has either failed to address or one that is beyond its scope in the context of existing institutional frameworks.

Measures in place to curb wildlife poaching/interference have met with resistance. They include antipoaching patrols by KWS personnel, the local administration and community wildlife scouts. Lately, the Eselenkei community has opted for negotiations in poaching cases that do not get to the KWS (ITDG-EA, 2001b). Otherwise, the culprits are charged in the law courts and, often jailed or fined (Kamugisha et al., 1997). Thereafter, the victims vent their anger on roaming wildlife and the antipoaching machinery and particularly the community wildlife scouts who allegedly spy on them. Following such encounters with poachers, the scouts have become reluctant to perform their duties leading to increased wildlife molestation outside ECA. The situation is worsened by low motivation due to poor remuneration, and delay in payment of salaries. Salaries for scouts are paid by the KWS through the Group Ranch Committee. Porini Ecotourism is currently paying these salaries following mismanagement of the funds by the Group Ranch Committee (ITDG-EA, unpublished report, 2000). Each community scout gets a monthly salary of KES5000 (US\$63).

\section{CONCLUSIONS}

This paper has demonstrated how pilot ecotourism initiatives under the PEP have changed local practices and attitudes towards wildlife. The impacts that include accumulation of savings by individuals are leading to social differentiation beyond traditional realms - further marginalizing the already impoverished groups/ individuals at the expense of the élite. Young well-to-do Maasai who are increasingly controlling power in the community following their exposure to the outside world and the wealth they have accumulated, are eroding traditional settings. This new form of marginalization ought to be addressed, especially through empowerment of individuals who can question modern institutions, and are motivated to actively participate in emerging livelihood options. 
There is also need to build the capacity of the Group Ranch Committee in sourcing and spearheading implementation of alternative livelihoods to pastoralism. This requires training of the Group Ranch Committee (and if possible individuals) in leadership and microenterprise management skills. Further, the committee needs to improve its negotiation and marketing skills if it is to effectively support on-going ecotourism initiatives and implement complementary activities. Although training and exposure tours offered by NGOs are partly addressing such needs, there is much more needed. Recent attempts by NGOs to support local institutions in conflict management ought to be intensified and integrated in mainstream development of natural resource management.

If the impacts of ecotourism on livelihood and NRM are to be sustained and/or improved, a number of other issues ought to be addressed. There is an urgent need to counter the expansion of cultivation by broadening the livelihood base particularly through promotion of ecotourism complementary technologies and microbusiness for income generation. Suitable strategies include empowerment of community groups that are active in steer fattening by building the required marketing capacity and setting up credit facilities. The local groups suffer from lack of knowledge of market networks and losses associated with wildlife-related diseases and drought. Individual initiatives to treat animals are hampered by inadequate income and limited access to drugs and vaccines.

\section{REFERENCES}

Barrow E, Lembuya P, Ntiati P, Sumba D. 1993. Knowledge, Attitudes and Practices Concerning Community Conservation in Group Ranches Around Amboseli National Park. AWF Discussion Paper series No. 11. African Wildlife Foundation: Nairobi.

Barrow E, Gichohi H, Infield M. 2000. Rhetoric or Reality? A Review Of Community Conservation Policy and Practice in East Africa. Evaluating Eden Series No. 5. IUCN: Nairobi.

DfID-NRSP. 2000. Department of International Development Strategy for Research on Renewable Natural Resources, Natural Resources System Programme. A Synthesis of Two Case Studies, where Wildlife Tourism and Pastoralism Interact in Kenya. Final Technical Report, Unpublished. ITDG.

Ecosystems. 1982: Amboseli/Lower rift regional study. A report prepared for Planning Unit, Ministry of Tourism and Wildlife, Republic of Kenya. Government Printers, Nairobi.

ITDG-EA. 2000. A synthesis of Eselenkei case study where wildlife, tourism and pastoralism interact. Unpublished report.

ITDG-EA. 2001a. Ecotourism exposure tour for Kathekani and Eselenkei communities, 1st-8th April 2001. DfID-NRSP (UK). Unpublished report.

ITDG-EA. 2001b. Eselenkei group ranch peace initiatives. Unpublished report.

ITDG-EA. 2001c. Conflict resolution: strengthening pastoralists livelihood. KIT, the newsletter of ITDG-EA.

Potter HL. 1989. Some thoughts on the prospects for intensification and diversification in Kenya Maasailand. In The Future of Maasai Pastoralists in Kajiado District (Kenya), Van Klinken, Ole SJ (eds). Proceedings of the Limuru Conference, Nairobi; 27-61. ASAL: Kajiado.

Southgate C, Hume D. 1996. Land, water and local governance in a Kenyan wetland in dryland: the Kimana group ranch and its environs. Rural resources rural livelihoods. Paper No. 4. The University of Manchester: Manchester.

Western D. 1997. Ecosystem conservation and rural development: the case of Amboseli. In Natural Connections. Perspectives in CommunityBased Conservation, Western D, Michael WR (eds). Island Press: Washington, DC. 